\title{
Sistem Informasi Produksi Barang Pada PT ABC
}

\author{
Uus Rusmawan ${ }^{1}$ \\ Universitas Bina Insani, Jakarta, Indonesia \\ e-mail: uusrusmawan71@gmail.com
}

\begin{abstract}
This study discusses the manufacture of goods production applications in manufacturing companies. Problems that arise include the difficulty of obtaining information relating to the process of production of goods from the purchase of raw materials, the use of raw materials for production, sale of finished goods and information on stock of raw materials for production and finished goods. One of the main objectives of this study is to overcome the deficiencies mentioned above in terms of presenting information and reporting the production process of goods. This research method uses waterfall. The results of research in the form of application of the production of goods provide one alternative solution to the availability of information systems for the production of goods for interested parties.
\end{abstract}

Keywords: information systems, production, purchasing, raw materials, finished goods, sales, stock

\section{PENDAHULUAN}

Proses produksi dalam sebuah perusahaan manufaktur memerlukan bahan baku yang pengadaannya melalui pembelian ke pemasok kemudian diolah menjadi barang jadi kemudian dilakukan penjualan atas barang jadi tersebut. Setelah bahan baku digunakan saat proses produksi maka perlu adanya laporan stok bahan baku dan stok barang jadi hasil produksi. Proses pembelian, produksi dan penjualanpun memerlukan laporan yang akurat dan tersediakan kapanpun diperlukan.

Sebuah perusahaan yang belum memiliki aplikasi tentu akan mengalami kesulitan jika pencatatan proses produksinya dilakukan secara manual atau hanya dengan menggunakan MS Excel atau MS. Word. Kesulitan yang sering terjadi pada sistem manual adalah dalam pencarian data dan pelaporan, padahal laporan merupakan ujung tombak dari sebuah proses dimana berbagai level managemen dapat mengambil keputusan dengan adanya laporan tersebut. Penelitian ini dibuat atas dasar hal - hal tersebut diatas.

Sistem informasi adalah susunan yang terdiri dari hardware dan software serta tenaga pelaksanaan yang bekerja dalam sebuah proses yang berurutan dan secara bersama-sama saling mendukung untuk menghasilkan suatu prosuk. (Gardner, 2016).

Sistem informasi menurut Robert A.Leitch dan K. Roscoe Davis (Jogiyanto, 2005) merupakan suatu sistem di dalam suatu organisasi yang mempertemukan kebutuhan pengolahan transaksi harian, mendukung operasi, bersifat manajerial dan kegiatan strategi dari suatu organisasi dan menyediakan pihak luar tertentu dengan laporan-laporan yang diperlukan.(Anisya \& Wandyra, 2016).

Pembelian adalah rangkaian tindakan untuk mendapatkan barang dan jasa melalui pertukaran dengan maksud untuk digunakan sendiri atau dijual kembali. Pada perusahaan dagang pembelian dilakukan dengan menjual kembali tanpa melakukan perubahan bentuk barang, sedangkan pada perusahaan manufaktur pembelian dilakukan dengan merubah bentuk barang yang dibeli dan menjualnya kembali. (Permata et al., 2017)

Bahan baku adalah persediaan yang dibeli oleh perusahaan untuk diproses menjadi barang setengah jadi dan akhirnya barang jadi atau produk akhir dari perusahaan. (Mussardo, 2019)

Persediaan merupakan sejumlah barang jadi, bahan baku, dan bahan dalam proses yang dipunyai perusahaan dagang dengan tujuan untuk dijual atau diproses lebih lanjut". Berdasarkan penjelasan, dapat disimpulkan bahwa persediaan adalah suatu istilah yang menyatakan segala hal dari sumber daya yang ada dalam suatu proses yang memiliki tujuan agar mengantisipasi segala kemungkinan yang terjadi baik karena adanya 
permintaan maupun masalah lain. (Tamodia, 2013)

Selling adalah suatu kegiatan yang memiliki tujuan mencari pembeli, mempengaruhi dan memberi petunjuk agar pembeli dapat menyesuaikan kebutuhannya dengan produk yang ditawarkan serta mengadakan perjanjian mengenai harga yang menguntungkan bagi kedua belah pihak. (Widharta \& Sugiharto, 2013)

Menurut M. Alan Jayaatmaja (2010:9), Bahan baku merupakan bahan yang digunakan pada proses produksi pada periode yang bersangkutan. Dalam sebuah perusahaan bahan baku dan bahan penolong memiliki arti yang sangat penting, karena menjadi modal terjadinya proses produksi sampai hasil produksi.(Haryana et al., 2017)

Mulyadi (2005:275) bahan baku adalah Bahan baku merupakan bahan yang membentuk bagian menyeluruh. (Muzawi et al., 2019)

\section{METODE PENELITIAN}

Penelitian dalam bentuk pembuatan aplikasi produksi barang ini menggunakan metode waterfall yang diawali dengan analisa kebutuhan sistem, membuat desain database, desain form, desain laporan. Kemudian dilanjutkan dengan membuat coding, testing dan implementasi dan perawatan aplikasi.

Analaisa kebutuhan sistem diawali dengan kebutuhan perangkat keras, perangkat lunak dan pengguna aplikasi. Desain form dimulai dari bentuk form login, menu utama, form - form untuk data master seperti user, barang, bahan, supplier dan customer. Desain form transaksi antara lain form pembelian, produksi dan penjualan.

Desain laporan antara lain berupa laporan data master, laporan data pembelian, produksi dan penjualan berikut laporan stok bahan dan barang jadi. Laporan tersebut menyediakan fitur dengan pencarian data berdasarkan tanggal, berdasarkan periode, per bulan, juga tersedia fitur laporan per nomor, per supplier, per pemasok, berdasarkan bahan baku dan barang jadi.

\section{HASIL DAN PEMBAHASAN \\ Desain Relasi Tabel (ERD)}

Gambar 1 adalah relasi tabel proses pembelian barang yang meliputi tabel bahan, pembelian, detail beli dan supplier.

Gambar 2 adalah relasi tabel proses produksi barang yang meliputi tabel bahan, produksi, detail produksi dan barang.

Gambar 3 adalah relasi tabel proses penjualan barang yang meliputi tabel barang, penjualan, detail jual dan customer.

Gambar 4 adalah form transaksi pembelian barang dengan atribut yang terdiri dari nomor pembelian, tanggal, kode supplier dan item-item barang yang dibeli. Pembelian barang menyebabkan bertambahnya stok bahan baku dan datanya direkam juga pada tabel stok bahan.

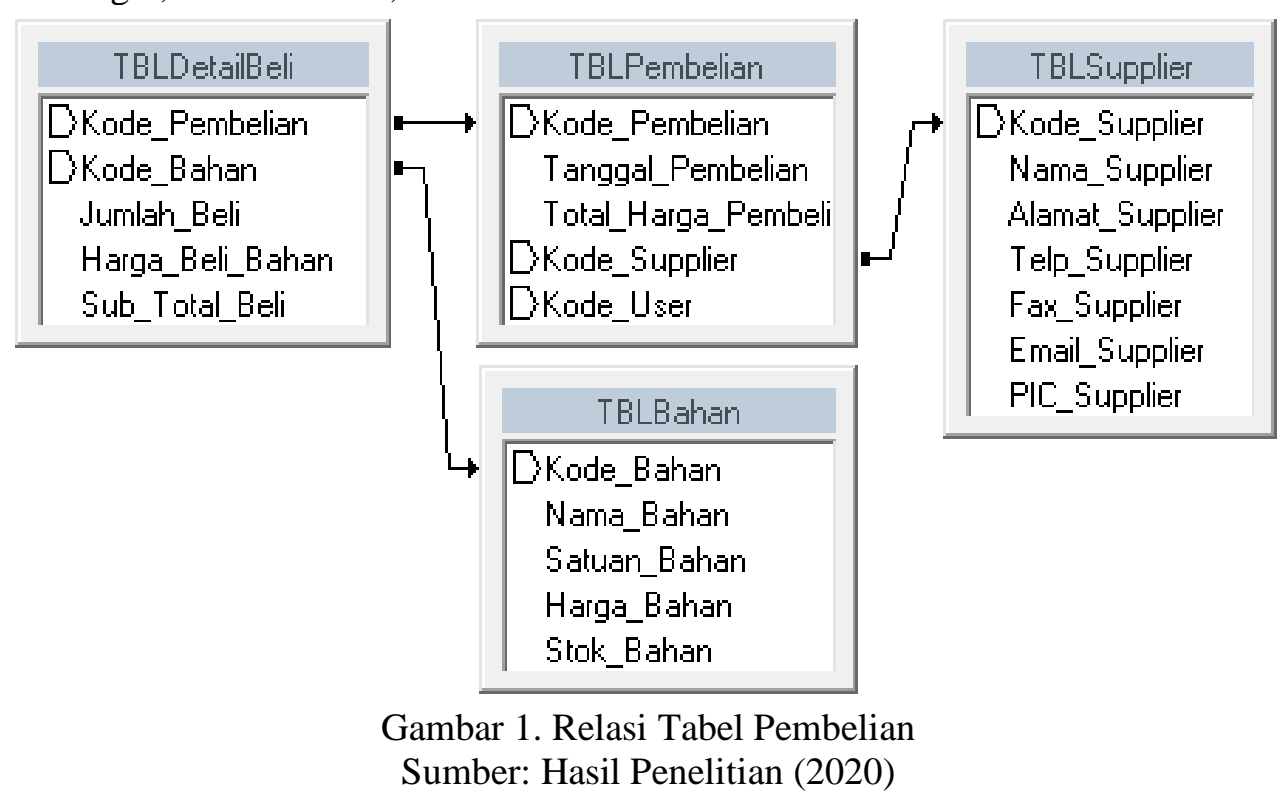




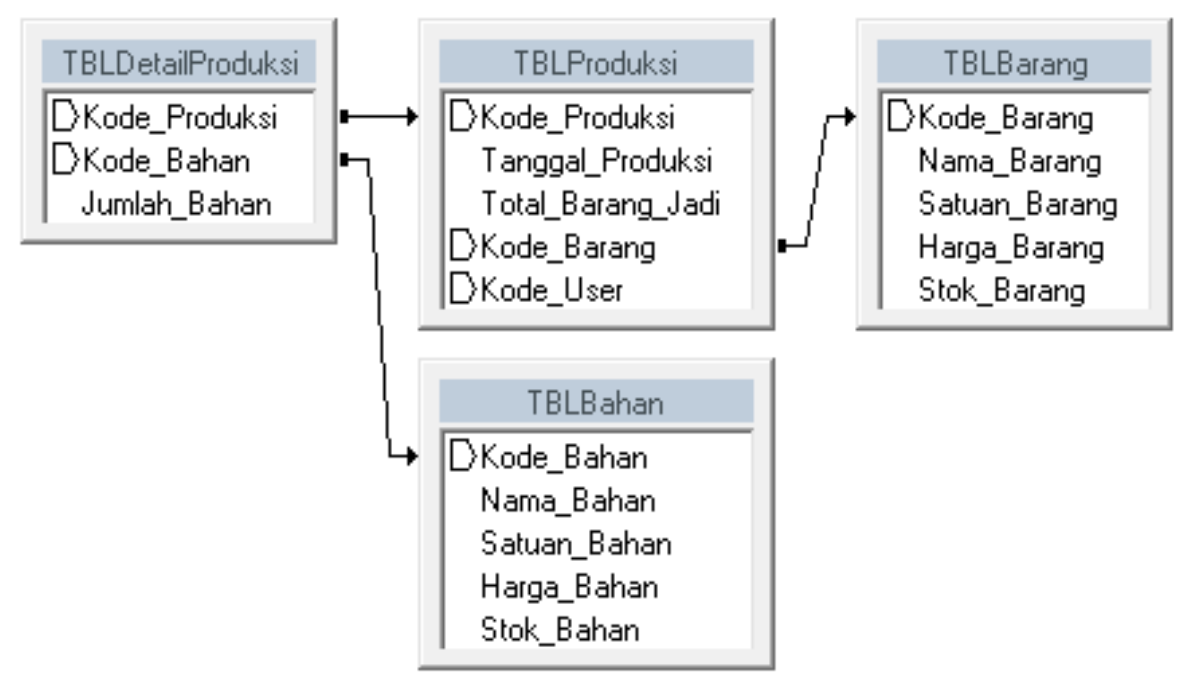

Gambar 2. Relasi Tabel Produksi

Sumber: Hasil Penelitian (2020)

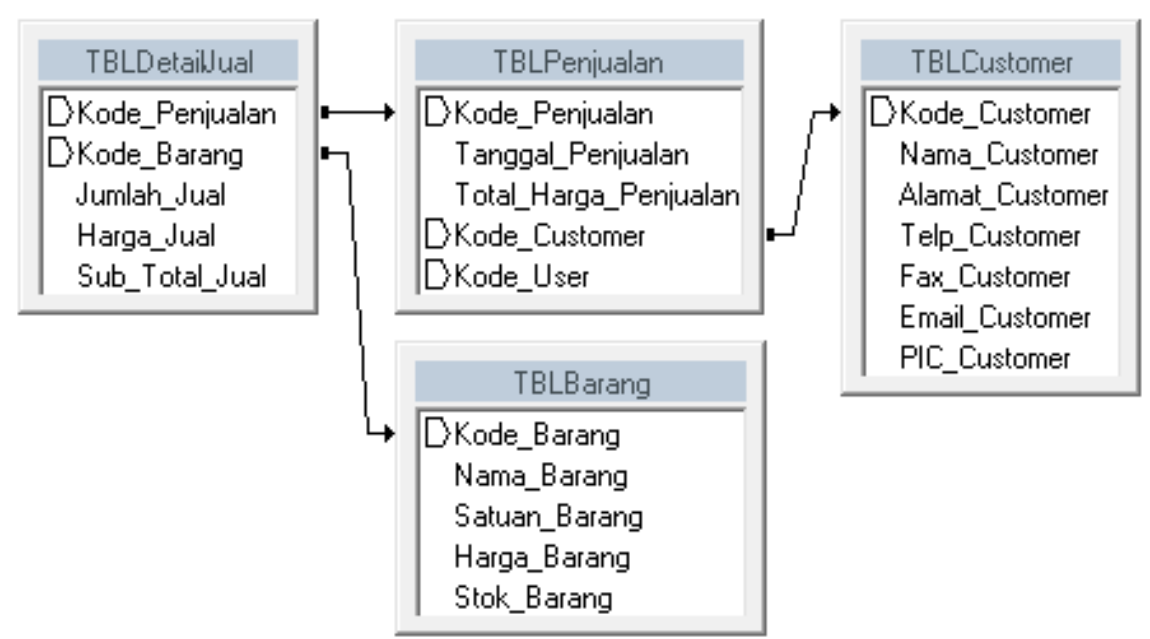

Gambar 3. Relasi Tabel Penjualan

Sumber: Hasil Penelitian (2020)

\section{Desain Form Transaksi}

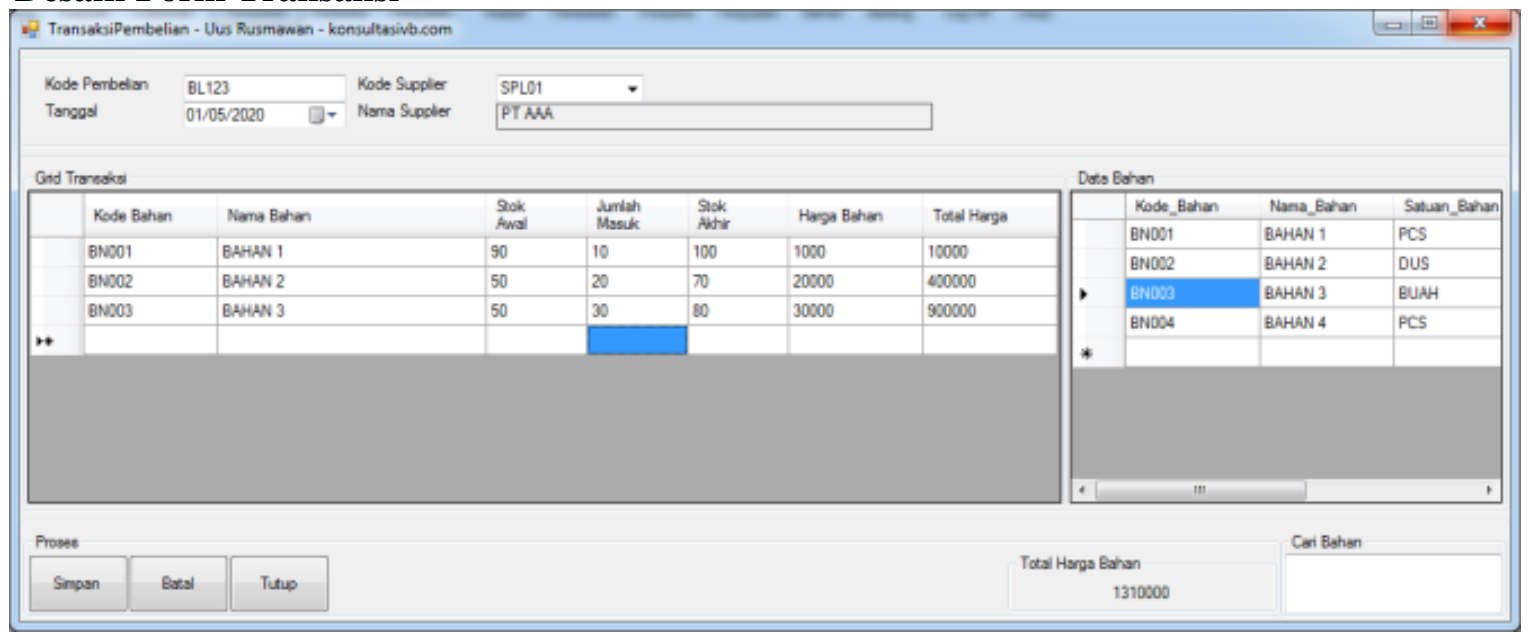

Gambar 4. Form Transaksi Pembelian

Sumber: Hasil Penelitian (2020) 
Gambar 5 merupakan nota pembelian bahan baku yang disimpan dalam aplikasi yang dapat dicetak ulang jika diperlukan.

Gambar 6 merupakan form transaksi produksi dengan atribut berupa nomor produksi, tanggal, kode barang jadi, jumlah produksi barang jadi dan item-item bahan baku yang digunakan. Proses produksi ini menyebabkan bertambahnya stok barang jadi dan mengurangi stok bahan baku.

Gambar 7 merupakan bukti produksi barang jadi dengan item data berupa nomor atau kode produksi, tanggal, jumlah hasil produksi, nama barang yang diproduksi dan item-item bahan baku yang digunakan untuk memproduksi barang tersebut.

\section{DATA PEMBELIAN}

\begin{tabular}{|c|c|c|c|c|}
\hline $\begin{array}{l}\text { Kode Pembelian } \\
\text { Tanggal Pembelian } \\
\text { Nama Supplier }\end{array}$ & $\begin{array}{l}\text { BL005 } \\
02 / \mathrm{Mei} / 2020 \\
\text { PT CCC }\end{array}$ & & & \\
\hline Nama Bahan & Satuan Bahan & Jumlah Beli & Harga Beli & Total \\
\hline BAHAN 1 & PCS & 10 & 1.000 & 10.000 \\
\hline BAHAN 3 & BUAH & 20 & 30.000 & 600.000 \\
\hline BAHAN 4 & PCS & 50 & 40.000 & 2.000 .000 \\
\hline
\end{tabular}

Gambar 5. Nota Pembelian Bahan Baku

Sumber: Hasil Penelitian (2020)

\begin{tabular}{|c|c|c|c|c|c|c|c|c|c|c|c|}
\hline \multicolumn{5}{|c|}{ 啰 TransaksiProduksi - Uus Rusmawan - konsultasivb.com } & +2 & 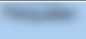 & 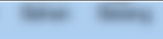 & $3=$ & 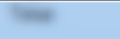 & & \begin{tabular}{|l|l|l|l|}
$口$ & 回 & $x$ \\
\end{tabular} \\
\hline \multirow{3}{*}{\multicolumn{2}{|c|}{$\begin{array}{l}\text { Kode Produksi } \\
\text { Tanggal }\end{array}$}} & \multicolumn{2}{|c|}{ P010520001 } & Kode Barang & $\mathrm{B} 0001$ & 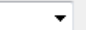 & Jumlah Barang Jadi & \multicolumn{2}{|l|}{2} & & \\
\hline & & \multirow{2}{*}{\multicolumn{2}{|c|}{$01 / 05 / 2020$}} & Nama Barang & \multicolumn{3}{|l|}{ BARANG 1} & & & & \\
\hline & & & & Stok Awal & \multicolumn{3}{|l|}{20} & & & & \\
\hline \multicolumn{5}{|c|}{ Grid Transaksi } & \multicolumn{7}{|c|}{ Data Bahan } \\
\hline & \multicolumn{2}{|c|}{ Kode Bahan } & Nama Bahan & & $\begin{array}{l}\text { Stok } \\
\text { Awal }\end{array}$ & $\begin{array}{l}\text { Jumlah } \\
\text { Pakai }\end{array}$ & Stok & & Kode_Bahan & Nama_Bahan & Satuan_Bahan \\
\hline & \multicolumn{2}{|c|}{ BN001 } & \multicolumn{2}{|l|}{ BAHAN 1} & 100 & 15 & 85 & & BN001 & BAHAN 1 & PCS \\
\hline & \multicolumn{2}{|c|}{ BNO02 } & \multicolumn{2}{|l|}{ BAHAN 2} & 70 & 20 & 50 & & BNO02 & BAHAN 2 & DUS \\
\hline & \multicolumn{2}{|c|}{ BN003 } & \multicolumn{2}{|l|}{ BAHAN 3} & 80 & 5 & 75 & & BNO03 & BAHAN 3 & BUAH \\
\hline & \multicolumn{2}{|c|}{ BNOO4 } & \multicolumn{2}{|l|}{ BAHAN 4} & 32 & 2 & 30 & • & BNO04 & BAHAN 4 & PCS \\
\hline \multirow{2}{*}{\multicolumn{5}{|c|}{ •* }} & & & & * & & & \\
\hline & & & & & & & & \multicolumn{3}{|c|}{1 III } & 1 \\
\hline \multicolumn{4}{|l|}{ Proses } & & & & & \multicolumn{2}{|c|}{ Cari Bahan } & & \\
\hline Simpan & & & Tutup & & & & & & & & \\
\hline
\end{tabular}

Gambar 6. Form Transaksi Produksi Barang

Sumber: Hasil Penelitian (2020) 


\section{DATA PRODUKSI}

$\begin{array}{llll}\text { Kode Produksi } & \text { P010520001 } & \text { Nama Barang } & \text { BARANG 1 } \\ \text { Tanggal Produksi } & \text { 01/Mei/2020 } & \text { Satuan Barang } & \text { PCS } \\ \text { Jumlah Hasil Produksi } & 2 & \text { Harga Barang } & 1.000\end{array}$

\begin{tabular}{|llr|}
\hline Nama Bahan & Satuan Bahan & Jumlah Bahan \\
\hline BAHAN 1 & PCS & 15 \\
BAHAN 2 & DUS & 20 \\
BAHAN 3 & BUAH & 5 \\
BAHAN 4 & PCS & 2 \\
\hline
\end{tabular}

Gambar 7. Bukti Produksi Barang

Sumber: Hasil Penelitian (2020)

Gambar 8 adalah form transaksi kode penjualan, tanggal, nama customer dan penjualan dengan atribut berupa nomor faktur penjualan, tanggal, kode supplier dan item-item item-item barang yang dijual.

Gambar 10 adalah laporan pembelian barang jadi yang dijual. Proses penjualan ini akan secara otomatis mengurangi stok barang jadi. bahan baku ke supplier. Laporan dapat ditampilkan berdasarkan nomor pembelian,

Gambar 9 adalah faktur penjualan barang berdasarkan nama supplier, per tanggal, per jadi kepada komsumen dengan item data berupa periode, bulanan dan tahunan.

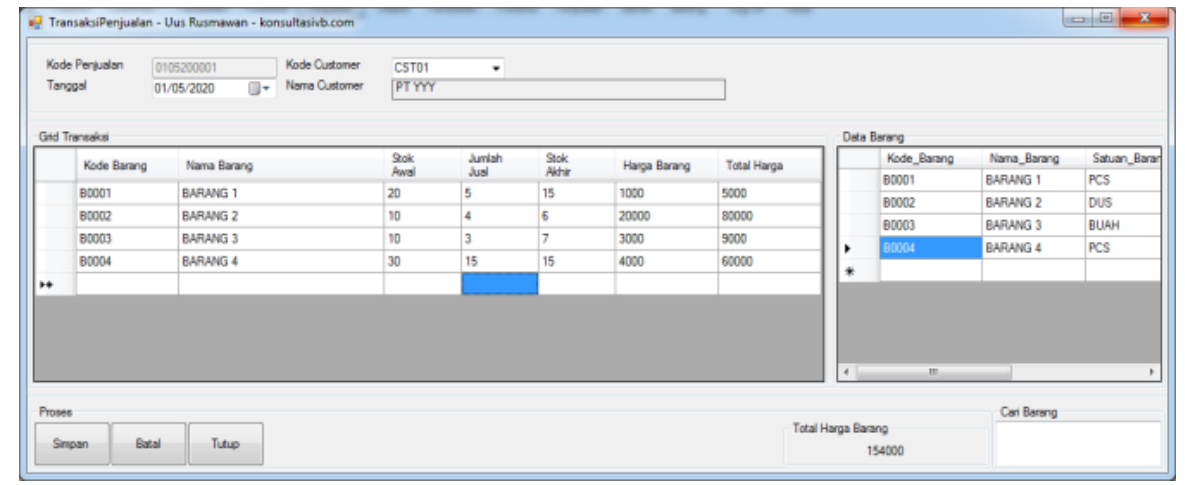

Gambar 8. Form Transaksi Penjualan

Sumber: Hasil Penelitian (2020)

\section{FAKTUR PENJUALAN}

\begin{tabular}{|c|c|c|c|c|}
\hline $\begin{array}{l}\text { Kode Penjualan } \\
\text { Tanggal Penjualan } \\
\text { Nama Customer }\end{array}$ & $\begin{array}{l}0205200001 \\
02 / \mathrm{Mei} / 2020 \\
\text { PT ZZZ }\end{array}$ & & & \\
\hline Nama Barang & Satuan Barang & Jumlah Jual & Harga Jual & Total \\
\hline BARANG 1 & PCS & 5 & 1.000 & 5.000 \\
\hline BARANG 2 & DUS & 1 & 20.000 & 20.000 \\
\hline BARANG 3 & BUAH & 2 & 3.000 & 6.000 \\
\hline BARANG 4 & PCS & 3 & 4.000 & 12.000 \\
\hline BARANG 6 & PAK & 4 & 12.000 & 48.000 \\
\hline
\end{tabular}

Gambar 9. Form Transaksi Penjualan

Sumber: Hasil Penelitian (2020) 


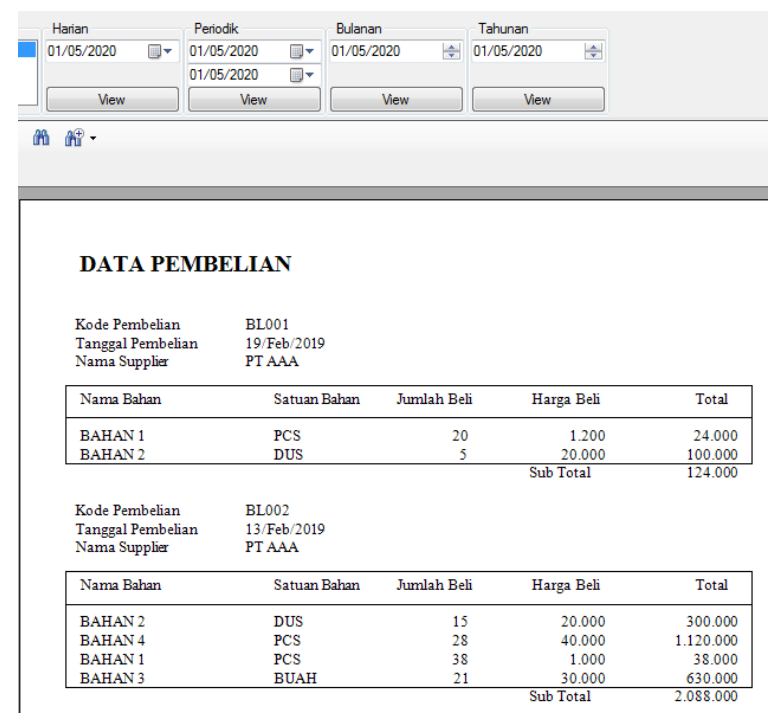

Gambar 10. Form Laporan Pembelian

Sumber: Hasil Penelitian (2020)

Gambar 11 adalah laporan produksi berdasarkan nama customer, laporan harian, barang. Laporan dapat ditampilkan berdasarkan minggunan, bulanan dan tahunan.

nomor produksi, berdasarkan, per tanggal, mingguan, bulanan dan tahunan.

Gambar 13 adalah laporan stok bahan barang jadi ke customer. Laporan dapat bulanan dan tahunan.

ditampilkan berdasarkan nomor penjualan,

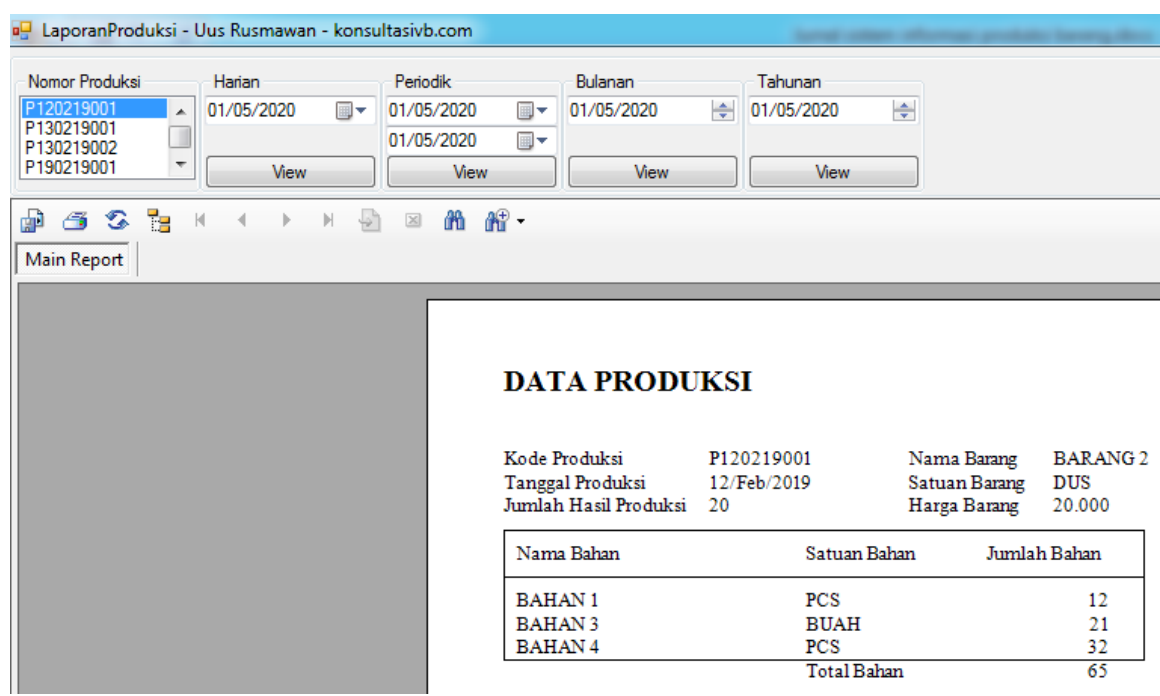

Gambar 11. Form Laporan Produksi

Sumber: Hasil Penelitian (2020) 


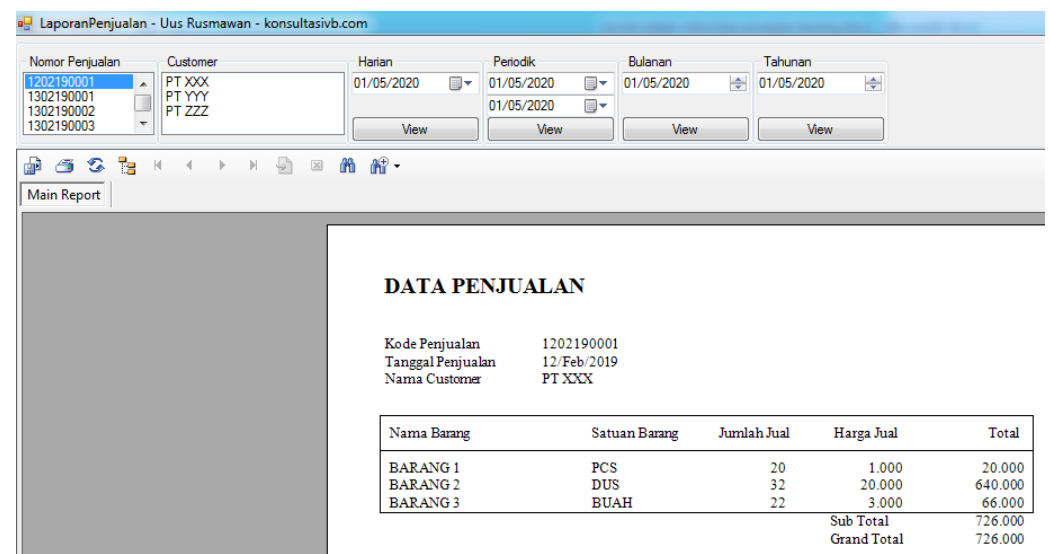

Gambar 12. Form Laporan Produksi

Sumber: Hasil Penelitian (2020)

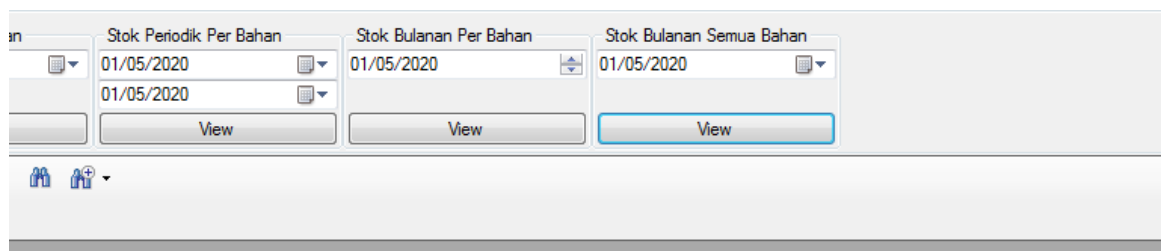

\section{DATA STOK BAHAN UMUM}

\begin{tabular}{|c|c|c|c|c|c|c|}
\hline $\begin{array}{l}\text { Kode Bahan } \\
\text { Nama Bahan } \\
\text { Satuan Bahan }\end{array}$ & $\begin{array}{l}\text { BNO01 } \\
\text { BAHA } \\
\text { PCS }\end{array}$ & & & & & \\
\hline Nomor & Tanggal & Kode Transaksi & Stok Awal & Masuk & Keluar & Stok Akhir \\
\hline 47 & $01 / \mathrm{Mei} / 2020$ & BL123 & 90 & 10 & 0 & 100 \\
\hline 50 & $01 / \mathrm{Mei} / 2020$ & P010520001 & 100 & 0 & 15 & 85 \\
\hline \multirow{3}{*}{$\begin{array}{l}\text { Kode Bahan } \\
\text { Nama Bahan } \\
\text { Satuan Bahan }\end{array}$} & \multirow{2}{*}{\multicolumn{2}{|c|}{$\begin{array}{l}\text { BNO02 } \\
\text { BAHAN 2 }\end{array}$}} & & & & \\
\hline & & & & & & \\
\hline & \multicolumn{2}{|c|}{ DUS } & & & & \\
\hline Nomor & Tanggal & Kode Transaksi & Stok Awal & Masuk & Keluar & Stok Akhir \\
\hline 48 & $01 / \mathrm{Mei} / 2020$ & BL123 & 50 & 20 & 0 & 70 \\
\hline 51 & $01 / \mathrm{Mei} / 2020$ & P010520001 & 70 & 0 & 20 & 50 \\
\hline
\end{tabular}

Gambar 13. Form Laporan Stok Bahan

Sumber: Hasil Penelitian (2020)

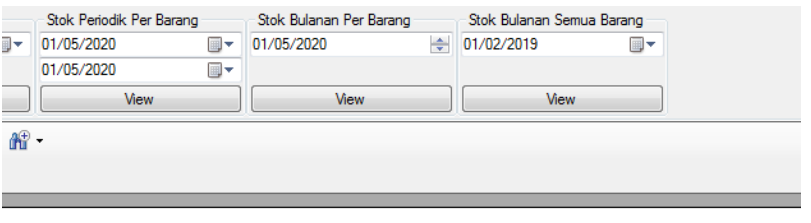

DATA STOK BARANG UMUM

Kode Barang B0001

Nama Barang BARANG

\begin{tabular}{|cllcccc|}
\hline Nomor & Tanggal & Kode Transaksi & Stok Awal & Masuk & Keluar & Stok Akhir \\
\hline 33 & $01 /$ Mei 2020 & P010520001 & 20 & 2 & 0 & 22 \\
34 & $01 /$ Mei 2020 & 0105200001 & 20 & 0 & 5 & 15 \\
\hline
\end{tabular}

Kode Barang $\quad$ B0002

Nama Barang BARANG

\begin{tabular}{|cllcccc|}
\hline Nomor & Tanggal & Kode Transaksi & Stok Awal & Masuk & Keluar & Stok Akhir \\
\hline 35 & $01 /$ Mei 2020 & 0105200001 & 10 & 0 & 4 & 6 \\
\hline
\end{tabular}

Kode Barang $\quad$ B0003

Nama Barang BARANG
Gambar 14. Form Laporan Stok Barang Jadi

Sumber: Hasil Penelitian (2020)

Gambar 14 adalah laporan stok barang jadi. Laporan dapat ditampilkan berdasarkan nama barang, laporan harian, mingguan, bulanan dan laporan tahunan.

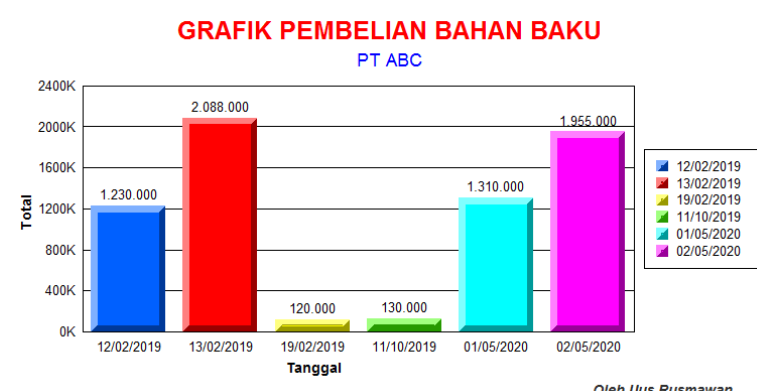

Gambar 15. Grafik Pembelian Bahan Baku 
Sumber: Hasil Penelitian (2020)

Gambar 15 adalah laporan pembelian bahan baku berupa grafik vertikal yang diambil dari seluruh transaksi pembelian bahan baku.

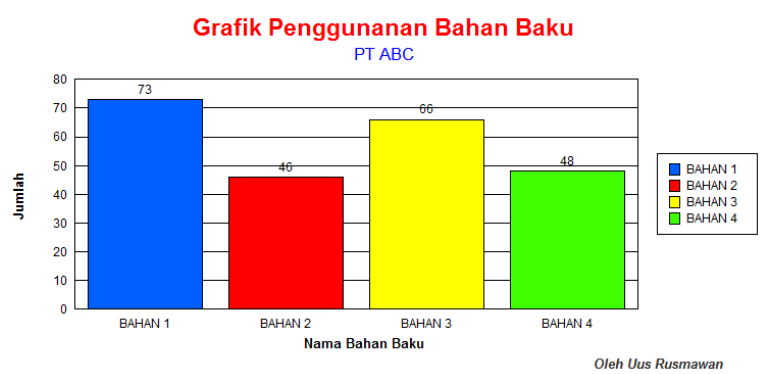

Gambar 16. Grafik Penggunaan Bahan Baku Sumber : Hasil Penelitian (2020)

Gambar 16 adalah laporan penggunaan bahan baku produksi grafik vertikal yang diambil dari seluruh proses produksi yang pernah dilakukan.

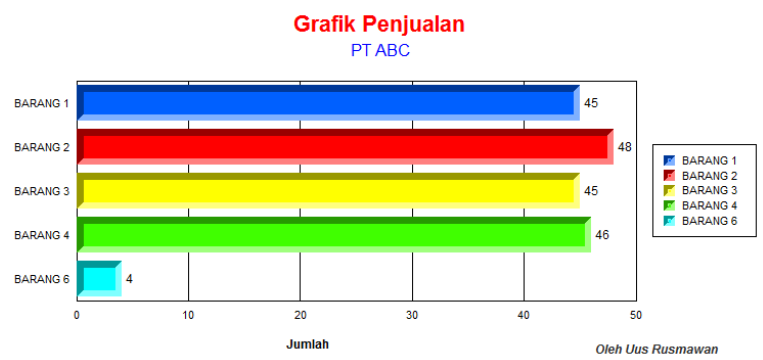

Gambar 17. Grafik Penjalan Barang Jadi

Sumber: Hasil Penelitian (2020)

Gambar 17 adalah laporan penjualan barang jadi berupa grafik horizontal yang diambil dari seluruh transaksi penjualan yang pernah dilakukan.

\section{KESIMPULAN DAN SARAN}

Dengan adanya aplikasi produksi barang ini maka beberapa kesulitan pencarian dan pelaporan data dapat teratasi termasuk diantaranya perhitungan stok barang dapat dilakukan secara otomatis dan akurat.

Mengingat keterbatasan waktu dalam penelitian ini maka dalam aplikasi ini masih perlu ditambahkan beberapa fitur pelengkap lainnya barupa pembayaran dalam proses pembelian belum memiliki fitur pembayaran kredit. Dalam proses penjualan juga belum memiliki pembayaran kredit. Diharapkan para peneliti berikutnya dapat melengkapi fitur tersebut diatas. Diawal analisa kebutuhan sistem, perusahaan yang bersangkutan hanya ingin memfokuskan pada proses pembelian, produksi dan penjualan yang mengarah pada kalkulasi stok bahan baku dan barang jadi sehingga hal-hal yang berkaitan dengan masalah keuangan atau pembayaran tidak dimasukan dalam aplikasi ini.

\section{DAFTAR PUSTAKA}

Anisya, \& Wandyra, Y. (2016). Rekayasa Perangkat Lunak Pengendalian Inventory Menggunakan Metode SMA (Single Moving Average) Berbasis AJAX ( Asynchronous Javascript and XML ). Jurnal Teknoif, 4(2), 11-17.

Gardner, E. S. (2016). No 主観的健康感を中心とした在宅高䟥者 における 健康関連指標に関する共分散構造分析 $T$ itle. 3(2), 1939.

Haryana, A., Rochman, A., \& Setyaningsih, A. (2017). Perancangan sistem informasi perencanaan dan pengendalian bahan baku pada home industri. Jurnal Sisfotek Global, $7(1)$,

87-95. http://journal.stmikglobal.ac.id/index.php/si sfotek/article/view/120

Mussardo, G. (2019). 済無No Title No Title. Statistical Field Theor, 53(9), 1689-1699. https://doi.org/10.1017/CBO978110741532 4.004

Muzawi, R., Tashid, \& Nasution, M. (2019). Sistem Monitoring Ketersediaan Bahan Baku Cor Beton Menggunakan Metode Market Basket Analysis. Jurnal Teknologi Dan Sistem Informasi Bisnis, 1(1).

Permata, D. N., Lambey, L., \& Tangkuman, S. (2017). Analisis Penerapan Sistem Informasi Akuntansi Pembelian Suku Cadang Pada Pt. Hasjrat Abadi Sudirman Manado. Going Concern: Jurnal Riset Akuntansi, 12(2), 905-916. https://doi.org/10.32400/gc.12.2.18366.201 7

Tamodia, W. (2013). Evaluasi Penerapan Sistem Pengendalian Intern Untuk Persediaan Barang Dagangan Pada Pt. Laris Manis Utama Cabang Manado. Jurnal Riset Ekonomi, Manajemen, Bisnis Dan Akuntansi, 1(3), 20-29.

Widharta, W. P., \& Sugiharto, S. (2013). Penyusunan Strategi Dan Sistem Penjualan Dalam Rangka Meningkatkan Penjualan Toko Damai. Jurnal Manajemen Pemasaran Petra, 2(1), 1-15. 